DOI https://doi.org/10.30525/978-9934-26-113-8-44

\title{
НЕФЕРМЕНТУЮЧІ ГРАМНЕГАТИВНІ БАКТЕРІЇ В ЕТІОЛОГІЇ ВНУТРІШНЬОЛІКАРНЯНИХ ІНФЕКЦИЙ: КЛІНІЧНІ, МІКРОБІОЛОГІЧНІ ТА ЕПІДЕМІОЛОГІЧНІ ОСОБЛИВОСТІ
}

\author{
Хандога Е. В. \\ лікар-бактеріолог вищої категорї \\ ВП «Василівський міжрайонний відділ \\ ДУ «Запорізький обласний центр контролю та профілактики хвороб \\ Міністерства охорони здоров'я України» \\ м. Василівка, Запорізька область, Украӥна
}

\author{
Остапенко А. О. \\ кандидат фармачевтичних наук, \\ дочент кафедри клінічної лабораторної діагностики \\ Державний заклад «Запорізька медична академія післядипломної \\ освіти Міністерства охорони здоров ` Украӥни» \\ м. Запоріжжя, Украӥна
}

Царьов В. В.

завідувач відділенням анестезіології та інтенсивної терапї

Запорізька обласна клінічна дитяча лікарня

м. Запоріжжя, Украӥна

Неферментуючі грамнегативні бактерії (НФГНБ) належать до провідних збудників нозокоміальних інфекцій (НI). Крім найбільш значущого з них - Pseudomonas aeruginosa - інфекції у людини можуть викликати представники інших родів, як-от Acinetobacter, Burkholderia, Stenotrophomonas, Chryseobacterium. НФГНБ, як правило, викликають НІ в осіб зі сприятливими чинниками (імунодефіцити, попередня антибіотикотерапія, ШВЛ, злоякісні новоутворення тощо). Клінічно важливою особливістю НФГНБ є висока частота резистентності мікроорганізмів до різних класів антимікробних препаратів. Найважливішим механізмом, що забезпечує полірезистентність у НФГНБ, є мембранні системи активного викиду (еффлюкс). Серед них найбільш вивчено МехАВOprM, MexCDOprJ, MexEF-OprN i MexXY y $P$. aeruginosa. Іншою важливою властивістю НФГНБ $є$ наявність у них міжклітинної сигнальної системи «quorum sensing» - механізму, який стежить за щільністю клітин бактеріальної популяції та відповідає за контроль 158 
продукції багатьох позаклітинних чинників патогенності, що забезпечує бактеріям подолання захисних сил макроорганізму при інфікуванні. Ще однією властивістю НФГНБ є здатність до формування біоплівки, структура та фізіологічні властивості якої забезпечують підвищення стійкості до антибіотиків, дезінфектантів і впливу з боку імунної системи й інших чинників макроорганізму.

НФГНБ, які найчастіше викликають НI, належать до кількох родів, й умовно їх можна розділити на оксидазопозитивні - роди Pseudomonas (крім видів P. luteola і P. oryzihabitans), Burkholderia, Moraxella, Chryseobacterium та оксідазонегативні - роди Stenotrophomonas, Acinetobacter, Bordetella (крім B. pertussis, B. avium, B. bronchiseptica, B. hinzii) [1-3].

Усі НФГНБ можуть бути виділені з різних джерел навколишнього середовища, однак клінічною значимістю характеризуються тільки деякі види вищевказаних родів. Зокрема, за результатами дослідження складу грамнегативних нозокоміальних збудників та їхньої чутливості до антибіотиків, P. aeruginosa була першим за частотою (30\%) мікроорганізмом, який виділяють у відділенні реанімації та інтенсивної терапії (ВРІT). 3 порівняно меншою частотою виділяли грамнегативні мікроорганізми родини Enterobacteriaceae (Escherichia coli - 18,4\%, Klebsiella pneumoniae - 14,6\%, Proteus spp. - 10\%, Enterobacter spp. - 7,6\%), за ними йде інший представник НФГНБ - Acinetobacter spp. (6,9\%) [4].

Pseudomonas aeruginosa посідає перше місце в етіології нозокоміальної пневмонії, пов'язаної здебільшого зі штучною вентиляцією легень (ШВЛ) [1,5]. Інфекції, що викликає Pseudomonas aeruginosa, характеризуються високим рівнем летальності.

Acinetobacter spp. У даний час дані назви 10 видів роду Acinetobacter, хоча за морфологічними властивостями та результатами біохімічних тестів виділено щонайменше 19 видів [2, 7]. Для рутинних клінічних цілей низку геномовидів (1, 2, 3 і 13TU) об'єднують у комплекс Acinetobacter calcoaceticus - Acinetobacter baumannii. Це пов'язано 3 тим, що більшість геномовидів не можна надійно диференціювати один від одного на основі стандартних біохімічних тестів і фенотипічних ознак. Подібно до P. aeruginosa, бактерії роду Acinetobacter дуже поширені в навколишньому середовищі. Деякі штами є толерантними до детергентів (наприклад, до мила), в зв'язку з чим ці мікроорганізми належать до найчастіших грамнегативних бактерій, що виділяють 3 рук медичного персоналу та у госпіталізованих пацієнтів. У 25\% здорового населення цей мікроорганізм колонізує шкірні покриви, а у 7\% - носоглотку [8]. Основними чинниками ризику виникнення внутрішньолікарняної пневмонії, викликаної Acinetobacter spp., є інтубація трахеї, попередня 
антибіотикотерапія, перебування в ВРIT. У позалікарняних умовах інфекції, викликані цим збудником, виявляють зрідка.

Основною ознакою більшості видів НФГНБ, імовірно, можна вважати те, що вони викликають інфекції у певних контингентів пацієнтів (перш за все, пацієнтів з імунодефіцитами), в зв'язку з чим їх частіше виявляють у спеціалізованих відділеннях. Винятком є P. aeruginosa, яка посіла 4-е місце за частотою серед збудників НІ в цілому та 1-е місце серед мікроорганізмів, що викликають нозокоміальні пневмонії. Важливою ознакою $є$ природна стійкість НФГНБ до багатьох антибіотиків. Це пов'язано з тим, що для багатьох мікроорганізмів основною екологічною нішею $є$ грунт, а серед грунтових мікроорганізмів відомо досить велике число штамів - продуцентів антибіотиків, а також з різноманіттям у цих представників різних позахромосомних елементів (наприклад, плазмід), здатних нести в складі генома детермінанти медікаментозної стійкості. Крім добре відомих механізмів резистентності до антимікробних препаратів у НФГНБ поширені системи еффлюкс, роль яких у множинної резистентності до антибіотиків, антисептиків і дезінфектантів в останні роки визнається вкрай важливою.

Наявність низки особливостей у НФГНБ позначається на епідеміології інфекцій, що їх викликають ці збудники. Зокрема, постійна контамінація госпітального середовища носіями, різноманітні механізми стійкості до антимікробних препаратів i здатність тривалий час персистувати в навколишньому середовищі надають цим мікроорганізмам змогу швидко адаптуватися в лікарняному середовищі $[10,11]$.

Одним із найважливіших методів боротьби 3 інфекціями, викликаними НФГНБ, повинна бути організація системи постійного молекулярно-мікробіологічного моніторингу в закладах охорони здоров'я для своєчасного виявлення нових епідемічних штамів. У спеціалізованих відділеннях, де лікують таких хворих, потрібно застосовувати суворішу систему протиепідемічних заходів, спрямованих на боротьбу з НІ.

НФГНБ, зважаючи на наявність у них природної стійкості до багатьох антимікробних препаратів і безлічі позахромосомних детермінант стійкості, являтимуть собою основну проблему в терапії НІ. У зв'язку з цим вважаємо за доцільне створення спеціалізованих референтних лабораторій, де будуть значно краще вивчені мікробіологічні i епідеміологічні аспекти НI, спричинені неферментуючими грамнегативними бактеріями. 


\section{Литература:}

1. Kiska D.L., Gilligan P.H. Pseudomonas. In: Murray P.R., Baron E.J., Jorgensen J.H., Pfaller M.A., Yolken R.H., eds.Manual of Clinical Microbiology. 8th ed. Washington: ASM Press; 2003. p. 719-728.

2. Gilligan P.H., Lum G., Vandamme P.A.R., Whittier S. Burkholderia,Stenotrophomonas, Ralstonia, Brevundimonas,Comamonas, Delftia, Pandorea, and Acidovorax. Ibid. p. 729-748.

3. Schreckenberger P.C., Daneshvar M.I., Weyant R S., Hollis D.G. Acinetobacter, chromobacter, Chryseobacterium, Moraxella, and other nonfermentative gram-negative rods. Ibid. P. 749-779.

4. Страчунский Л.С., Решедько Г.К., Рябкова Е.Л. идр. Рекомендации по оптимизации антимикробной терапии нозокомиальных инфекций, вызванных грамотрицательными бактериями в отделениях реанимации и интенсивной терапии. Пособие для врачей.Смоленск: Боргес; 2002. 22 с.

5. Quinn J.P. Clinical problems posed by multiresistant nonfermenting gram-negative pathogens. Clin Infect Dis 1998; 27 (Suppl.):S. 117-124.

6. Osmon S., Ward S., Fraser V.J., Kollef M.H. Hospital mortality for patients with bacteremia due to Staphylococcus aureus or Pseudomonas aeruginosa. Chest 2004; 125:607-616.

8. Seifert H., Dijkshoorn L., Gerner-Schmidt P., Pezler N., Tjernberg I., Vaneechoutte M. Distribution of Acinetobacter species on human skin; comparison of phenotypic and genotypic identification methods. J Clin Microbiol 1997; 35:2819-25.

9. McDonald L.C., Banerjee S.N., Jarvis W.R. Seasonal variation of Acinetobacter infections: 1987-1996. Nosocomial Infections Surveillance System. Clin Infect Dis 1999; 29:1133-7.

10. Laing F.P.Y., Ramotar K., Read R.R., et al. Molecular epidemiology of Xanthomonas maltophilia colonization and infection in the hospital environment. J ClinMicrobiol 1995; 33:513-8.

11. Liang X., Pharm X., Olsen M.V., Lory S. Identification of genomic island present in the majority of pathogenic isolates of Pseudomonas aeruginosa. J Bacteriol 2001; 183:843-53. 